American Research Journal of English and Literature

ISSN (Online): 2378-9026

Volume 4, Issue 1, 2018, 1-11 Pages

DOI:10.21694/2378-9026.18003

AMERICAN RESEARCH JOURNALS

An Academic Publishing House

\title{
Conflictual Ideologies in Victorian Novels and Poetry
}

\author{
Md. Nazmul Haque ${ }^{1}$, Md. Amirul Islam², Mst. Ummay Tohfa ${ }^{3}$ \\ 1,2,3 Lecturer, Department of English, First Capital University of Bangladesh, Shahnaz Mansion, Alamdanga \\ Road (Pouro College Para), Chuadanga-7200, Bangladesh \\ nazmulhaqueibd@gmail.com
}

Abstract: This paper's grave concern revolves around the different sorts of conflictual ideologies- conflicts between faith and doubt, moral values and materialistic views and freedoms and restrictions- of Victorian novels and poetry. This paper examines how scientific advancement, the rapid growth of industrialization, Darwin's theory of evolution by natural selection and the concept of communism of Victorian age result in uncertainty, confusion, class distinction and of course dissatisfaction with life that exert a tremendous effect on Victorian people and consign lots of ideological contradictions to Victorian novels and poetry. This is because, this paper dissects Victorian conflicts of faith and doubt in consideration of Victorian people's approaches with respect to scientific prosperity, values and materialistic attitudes in view of social norms and freedom and restrictions in the light of sex. As the esoteric philosophy to the life of Victorian literary writings divides Victorian poets and novelists into different ideological worlds, some Victorian writers' principles center around faith, moral values, and restrictions and the other groups are in the favor of doubt, materialism and freedom and the rest are in between.

Keywords: Conflict, Victorian faith, doubt, uncertainty, morality, materialistic view, freedom, restriction. INTRODUCTION

In this paper, the star attraction is to focus on how Victorian novels and poetry are influenced by the contradicted ideologies existed in the Victorian society. As the literature is the imitation of real life (Abrams, 1971), almost all of the Victorian novels and poetry can be proved to be fruitless if we keep all these conflictual ideologies aloof from consideration. Because of this, the ideological conflicts of Victorian literature are worth thinking, talking and of course, writing about. As a matter of fact, in the $19^{\text {th }}$ - century Victorian period, the rapid growth of industrialization, Darwin's theory of evolution by natural selection ${ }^{1}$ and the concept of communism bring a notable change both in livelihood and philosophy of life of Victorian people and this change is pervasive in Victorian novels and poetry. In addition, industrialization that causes segregations and instabilities in Victorian society creating a gap between the working class and the owner class, slums, child labor, corruption and criminality makes the Victorian people materialistic. Industrialization, in this way, leaves a negative impact on the thoughts of the Victorian people and of course on the Victorian writers (Wrongly, 1931). As Charles Dickens in his novel states the problem caused by the rapid growth of industrialization:

"......, it was a town of unnatural red and black like the painted face of a savage. It was a town of machinery and tall chimneys, out of which interminable serpents of smoke trailed themselves forever and ever and never got uncoiled. It had a black canal and a river that ran purple with ill-smelling dye, and vast piles of building full of windows where there was a rattling and a trembling all day long, and where the piston of the steam-engine worked monotonously up and down, like the head of an elephant in a state of melancholy madness"(Charles Dickens, 1854).

Likely, at the early Victorian time, the theory of evolution coined by Charles Darwin is published in the book titled "On the Origin of Species by Means of Natural Selection (1859). This theory questions the religious faith 
and scientific knowledge of the Victorian people and puts them into the world of confusions and uncertainty. And therefore this Victorian crisis of faith or the ideological conflict of doubt and faith appears clearly in the poetry of Matthew Arnold, Robert Browning and Alfred Tennyson, prominent poets of Victorian-era while Matthew Arnold seems to be pessimistic, Robert Browning to be optimistic and Alfred Tennyson is partly optimistic and partly not in their poetry with regard to the conflict between science and religion. Again the concept of communism and industrial capitalism give birth to many conflictual ideologies in Victorian literature. In a like manner, the conflict in the question of moral values and materialistic views appears to be of paramount importance in Victorian literature because of the loss of religious faith. Victorian people become morally degraded and so most of the themes and the characters of the poetry and novels respectively seem to be materialistic. Sometimes we find the poets and novelists are confused themselves in their ideologies. For instance, Matthew Arnold in his poetry concerns with the Victorian crisis of faith and morality. This is why he finds the sea waves melancholic and withdrawing in this poem "Dover beach" but he explicates his opposite contradicted ideas saying that " ..... it is time to Hellenized and to praise knowing for we have Hebraised too much and have overvalued doing (Matthew Arnold,1867-1868). So it is an acknowledged fact that Matthew Arnold himself is confused account of his ideologies. In the same manner, the contradiction between moral values and materialistic approaches of Victorian people may be considered to be the main theme of Victorian novels. Because this (Victorian age) was an area that was full of prudery, morality, and sexual repression (Wohlfarth, 2003). This conflict is, in fact, the lifeblood of the Victorian novels. Charles Dickens "regarded as the greatest novelist of the Victorian era" skillfully shows the conflict between moral values and materialistic attitude (Wikipedia/Charles Dickens). Most of the Victorian characters of Charles Dickens's novels - Miss Havisham, Estella, Compeyson, Matthew pocket, Herbert pocket, Cousin Raymond, Georgiana and Pip also in "Great Expectations", Master William Bilfil, Squire Western, Lord Fellamar and Lady Bellastan in "Tom Jones", Thomas Gradgrind, Josiah Bounderby and James Harthouse in "Hard Times" are materialistic in thoughts and actions that spark off contradiction with the thoughts of the rest of the characters who have moral values. Again the characters of William Makepeace Thackeray's novel "Vanity Fair" - Becky Sharp and Georg Osborne and Emily Brontë's novel "Wuthering Heights" - Catherine Earnshaw, Hindley Earnshaw, Joseph, Frances Earnshaw, Mrs. Linton and even Heathcliff- are materialistic in thoughts and conducts. The purpose of the paper is also to expose the contradiction between freedom and restriction in the light of sex. So it can be finally noted that conflictual ideologies prevalent in Victorian novels and poetry are, in fact, worth talking about.

\section{METHODOLOGY}

In qualitative research method, taking into account of Victorian crisis of faith, rapid growth of industrialization, social restrictions to the women and restlessness, the comparative study of Victorian social as well as religious norms and Victorian novels and poetry and textual analysis of some Victorian poetry - Dover Beach, Scholar Gipsy, In Memoriam, The Cry for the Children, and Angel in the House- and novels - Hard Times, Great Expectations, Wuthering Heights, The Women in White, East Lynne, Tess of the d'Urbervilles and Pride and Prejudice- have been done applying different sort of techniques and methods to find out Victorian conflictual ideologies hidden in words, phrases and sentences. Many research articles and books written on these very concerned issues have been sometimes summarized and sometimes analyzed through empirical observations for collecting data from direct and indirect sources to demonstrate our findings.

\section{CONFLICT BETWEEN FAITH AND DOUBT}

"There lives more faith in honest doubt,

Believe me, than in half the creeds."

(In Memoriam, Section: XCVI, Line: 3374-3375) 
As a consequence of rapid scientific and industrial progress or the theories of Evolution and Communism, Victorian people and of course the literary writers are consigned to reach the acme of religious confusion or spiritual loss or conflict between faith and doubt. It is an admitted fact that the Victorian people and writers are found to be divided into two idealistic worlds. So if one group goes in the favor of faith or religion, the other is of course in the favor of doubt. So the conflict in ideologies is a must. As much ink is spilled over writing or enough debate is tabled regarding this very issue, the topic conflict between faith and doubt or science and religion places in the different sorts of Victorian literary devices especially in the Victorian poetry as "poetry is the criticism of life" (Matthew Arnold, 2009). This is because Hugh Walker comments:

"...it is curious that in the year 1850 both Tennyson and Browning produced poems in which the religious element is more prominent than it is in anything they had previously written" (HughWalker, 1931).

Needless to say, hundreds of books like "History of the Conflict between Religion and Science" (1875), "On the Origin of Species" (1859) and "The Warfare of Science with Theology in Christendom (1876) by John Draper, Andrew Whites, and Charles Darwin respectively are written on this conflict. This is why, being the children of the time, Matthew Arnold, Robert Browning, Alfred Tennyson and Cristina Rosetti started concerning with this very conflict through their poetry and of course it becomes the mirror on which the conflict between Victorian faith and doubt are clearly reflected. To lament on the loss of faith, Matthew Arnold who connects his target readers to social issues (George Landow, 1986) or to Victorian crisis of faith through his poetry states in his poem:

\section{"The Sea of Faith}

Was once, too, at the full, and round earth's shore

Lay like the folds of a bright girdle furled.

But now I only hear

Its melancholy, long, withdrawing roar,

Retreating, to the breath

Of the night-wind, down the vast edges drear

And naked shingles of the world."

(Dover Beach, Line: 21- 28)

In these quoted lines, making an explicit comparison between Victorian religious faith and sea, Arnold, in truth, laments over the transition from the age of faith into the age of skepticism, uncertainty or turbulence. The sea of faith was, to Arnold, full to the brim in past. It had flown with great energy and left its vigorous waves on the seashore. But now the poet hears the melancholic sounds of withdrawing waves. More clearly, religious faith of the Victorian people is replaced by agnostic, atheistic or skeptic thoughts.

Again, Matthew Arnold explicates the religious doubt or spiritual loss of a modern man of Victorian age in his poem. As he states:

$$
\begin{aligned}
& \text { “......this strange disease of modern man, } \\
& \text { With its sick hurry, its divided aims } \\
& \text { Its heads o'ertaxed, its palsied hearts," }
\end{aligned}
$$

(The Scholar-Gipsy, Line: 203-205)

This disease, actually, indicates the religious or spiritual barrenness and the victory of the irreligious or doubtful thoughts or immoral actions. Which is why the poet instructs the scholar-gypsy to escape from the university 
to the pastoral settings in search of the real meaning of life from beginning to end of the poetry in which doubt and immorality prevail over faith and spirituality.

Likewise, Alfred Lord Tennyson considered to be one of the most well-liked British poets during more of Queen Victorian period (Ten of the Greatest: British Poets, 2017) questions faith in God, in nature and even in science without any hesitancy in his poetry. In the truest sense of the term, we observe that Tennyson possesses mixed feeling about scientific progress. This is why, Tennyson acknowledges scientific advancement as a revolution in the path of hitting the acme of development of the nation and simultaneously concerned about the conflict between the theory of evolution and the Christian Scripture's notion of God's direct creation ability like most of the Victorian people whose faith is being tempted by Charles Darwin's theory of Natural Selection. In this connection, Tennyson sometimes goes in the favor of religion and sometimes is in the favor of doubt or religion. He is, actually, in between. This is because Tennyson explicates his sufferings from the conflict of faith and doubt in his poetry. In the poems 'The Lotos-Eaters'and 'Locksley Hall' the speakers are wild to abandon modern society and return to a savage lifestyle in the jungle. In the poem, 'In Memoriam' the Victorian poet concerns with this idea saying:

"We have but faith we cannot know....

For knowledge..."

(In Memoriam: Line: 21-22)

But in every poem, Tennyson seems to arrive at the conclusion saying that we should have faith in scientific progression and of course in our religion. He is, in fact, reluctant to reject belief and to accept knowledge as the path of solution for the Victorian crisis of faith. In truth, he is ardent to reconcile Victorian belief with knowledge. So, it can be noted that Tennyson wants to solve the problem originated from the Victorian conflicts of faith and doubt by reconciling his faith with knowledge. In a similar manner, the Victorian crisis of faith and doubt has clearly appeared in the poetry of Elizabeth Barret Browning, one of the most prominent of the Victorian poets. Her very poem 'The Cry of the Children' speaks about the suffering and faithlessness of the Victorian people through child labor, no doubt an acute issue of her time. Even though, Matthew Arnold's poem 'Dover Beach' deals with the Victorian crisis of faith from the spiritual point of view. Elizabeth Barret Browning's poem 'The Cry of the Children' concerns with this very issue from the practical or social point of view. Children ask help to God but he doesn't pay heed to them.

"Is it likely God, with any around Him,

Hears our weeping anymore"

(Line: 227-228)

But this scene is somewhat different for the dead girl. She looks happier because she is now out of the industrially developed Victorian society. And she has not been compelled to do a lot of works in mills and factories around fourteen to fifteen hours with little wages. In truth, the children symbolize the working class people, the worst sufferers of the Victorian society. This industrial unscrupulous society is established through the blood and sweat of the working classes people. Truly, the children are innocent but they are forced to go against the God. As the poem states:

"How long," they say, "how long, 0 cruel nation,

Will you stand, to move the world, on a child's heart, -

('The Cry of the Children': Stanza: xiii, Line: 33-34)

This is because the faith of Victorian children declines. Again the poet says: 
"But, no!" say the children, weeping faster,

"He is speechless as a stone; ...

Do not mock us; grief has made us unbelieving -

We look up for God, but tears have made us blind."

Do ye hear the children weeping and disproving,"

('The Cry of the Children': Stanza: xi, Line: 125-126 \&131-133)

Here, we are not considering all Victorian people to be atheists. Because the loss of faith doesn't mean atheism. It, to us, means confusion in respect of religious faith or the Victorian conflict between faith and doubt. Because scientific discoveries, industrialization and the theory of evolution make the people skeptic regarding religion and even in science.

\section{Contradiction between Moral Values and Materialistic Views}

As Victorian age overflows with the contradiction between moral values and materialistic views, it brings an adverse effect on Victorian people and literature. It can be easily avowed that the most of the upper class characters of the Victorian novels judge the other people around them with the thread of wealth, money and property and familial or social status instead of social or moral values and the lower or middle class characters are found good until they are pushed materialistic thought into their blood of how to make money, how to learn artificial dress and manner codes of ostensible gentility and how to grasp higher social status, love and happiness as Matthew Arnold in his essay "The incompatibles" said "We are commercial people..." (Matthew Arnold,1885) As a matter of fact, when the Victorian people become materialistic in thoughts and actions or the members of the self-named upper class, the society finds them immoral snobbish, revengeful and of course rootless. In the novels, Charles Dickens, Makepeace Thackeray, and Trollope explicate the conflict between materialistic ideas and moral values exposing the materialistic Victorian idea of a gentleman. In Charles Dickens novel Great Expectations, the protagonist Pip, a member of the lower Victorian class, lives with his sister Mrs. Joe and brother-in-law Mr. Joe, a blacksmith in the profession, is innocent and morally good until starts keeping in touch with Miss. Havisham and Estella, women of materialistic thoughts and actions. At the very outset of the novel, we observe that Miss. Havisham and Estella start instigating Pip to be a gentleman by earning much money and wealth, learning artificial manner and dress codes to get love of Estella because these characters like Victorian people believe that 'wealth, social status, apparel, wealth and respectable family'(A True Gentleman in Great Expectations/www.ukessays.com) and learning Victorian aristocrat society's selfmade dress and manner codes are the ways of establishing a person as a gentleman. Modesty, good manners, morality, and humanity are not in the matter of consideration in respect of this very issue. This is because, even though Compeyson is proved to be corrupt, Magwitch regards him as a gentleman (Charles Dickens,1993). Again, Estella who possesses gentility in her thoughts and behaviors according to Victorian social norms denies the fact that she is the daughter of Magwitch (Henry Suhamy, 1971). Even Pip is, at last, able to establish himself as a so-called Victorian gentleman without moral or human values. For, Pip states his condition when Magwitch goes to meet him:

"For an hour or more, I remained too stunned to think; and it was not until began to

think that I began fully to know how wrecked I was and how the ship in which I had

sailed was gone to pieces...."

(Chapter 39, Great Expectations)

Again,

American Research Journal of English and Literature

Page 5 


\begin{abstract}
“Miss Havisham's intentions towards me, all mere dream; Estella not designed for me... but sharpest and deepest pain of all- it was for the convict, guilty of I knew not what crimes and liable to be taken out of those rooms where I sat thinking, and hanged at the Old Bailey door that I had deserted Joe"( Charles Dickens, 1993).

In a similar manner, when Magwitch comes back, he acknowledges Pip's contradicted lavish habits as the symptom of a Victorian gentility. Truly, losing control over oneself in respect of spending money lavishly can't be the characteristic of a true gentleman. This very expensive habit can, in fact, destroy the moral values of a man and when moral values will not be developed in a person, he or she will be the product of materialistic ideologies and so the people around him must suffer from the materialistic cruelties For, we observe that Estella, a lady of aristocratic Victorian society, misbehaves with Pip using many harsh and insulting words like "thick boots" and "coarse hands". And Pip after becoming a materialist did the same with his brother-in-law Mr. Joe who brought him up when he comes to meet Pip. As Pip comments:
\end{abstract}

"Not with pleasure though I was bound to him by so many ties; no; with considerable disturbance, some mortification, and a keen sense of incongruity. If I could have kept him away by passing money, I certainly would have paid money. I certainly would have paid money. My greatest reassurance was that he was coming to Barnyard's Inn, not to Hammersmith, and consequently would not fall in Bentley Drummule's way"(Chares Dickens,1861).

In these very lines, the very word 'mortification' is making clear that Pip feels embarrassed about Mr. Joe's sudden visit. Truly, Pip, a gentleman according to the Victorian notions of gentility, denies his low origin or root. Likewise, Pip's snobbish attitude clearly appears when he travels to Miss Havisham's home named Satis House for celebrating her birthday. Pip suffers from a superiority complex and so feels a deep sense of revulsion at sharing a coach with two lower class people. As Pip exposes his snobbery saying:

"There are two convicts going down with me....... Their coarse mangy ungainly outer surface as if they were lower animals"(Chares Dickens,2001).

To judge two convicts to be 'lower animals' is a matter of irony because his adviser Magwitch is a criminal and his beloved Estella's parents Molly and Magwitch are two criminals too. Moreover, Pip becomes so materialistic that he is reluctant to visit home in which he has been reared up by his father and mother like brother-inlaw and sister Mr. and Mrs. Joe. As a materialist, he sends some material products only like 'cold fish' and a 'barrel of oysters' to home. In truth, if he had not been a so-called materialist Victorian gentleman, he would have visited home and kept in touch with his family. It can be said that Victorian gentleman without moral or social values or humanity is like the dodder. ${ }^{3}$ As a matter of fact, Charles Dickens establishes an idea of a true gentleman through the character Mr. Joe. The brother-in-law of Pip Mr. Joe is a true gentleman though he is a blacksmith and so neither he possesses lots of money nor does he know the artificial dress and manner codes. He never forgets his root and therefore he continues his family trade and maintains his family well with his lowest income. In a similar manner, he even brings an orphan brother-in-law Pip up as a father. He loves him more than his own sister. As Pip praises Mr. Joe as a "good-natured, sweet-tempered, easy-going foolish, dear fellow - a sort of Hercules in strength....". (Dickens, 2001)

Again when Mr. Joe marries Biddy after the death of Mr. Joe, Pip says to Biddy:

"Dear Biddy, you have the best husband in the world." (Dickens, 2001)

So it can be noted easily that a man according to Charles Dickens can't be a gentleman with money or respectable familial status or artificial manner and dress codes but he can be a gentleman only at heart or through practicing moral values. As Matthew Pocket comments:

"No varnish can hide the grain of wood; and that more varnish you put on the more grain will express itself." (Dickens, 2001) 
Comparably, the conflictual ideologies are crystal clear in another Victorian novel "Wuthering Heights" by Emily Bronte. In this novel Catherine Earnshaw, a female protagonist and a lady of materialistic Victorian society, suffers from a superiority complex and therefore she is deeply antipathetic to the lower class people around her. In her view, a man without much money and social status can't expect good treatments from the upper class materialistic Victorian people. This is why Cathy starts disdaining Hareton as he doesn't come of an upper-class family. Cathy does maltreatment with Hareton saying:

$$
\begin{gathered}
\text { "I can't endure... } \\
\text { I despise you..." (Emily Bronte, 1999) }
\end{gathered}
$$

On the other hand, she has a deep sense of sympathy with her cousins Edgar Linton a man of aristocrat society. This is why, since Linton asks Cathy:

"You don't despise me, do you? In reply she says despise you? (Bronte, 1999).

Cathy replies:

No..... [......] I love you better than anyone living (Bronte, 1999).

Likewise, Heathcliff "considered to be a Byronic hero" (Wuthering Heights_\#Characters/ https.//en.wikipedia. org) has to be disdained in every step of his life by most of the family members of the aristocratic Earnshaw family as he is an orphan boy without any social status. He is so unwelcome in this family that he is addressed as a 'thing' or 'it'. He has no freedom of entering into the rooms of Catherine and Hindley. Edgar Linton, the cousin of Catherine, degrades him time and again. The novel narrates:

"He wants that authority should hang him at once." (Bronte, 1999. p.55 ). Isabella, another character without moral values, judges Heathcliff to be a "frightful thing" and also instructs to "put him in the cellar" (Bronte, 19999. p.56)

Likewise, when Hindley emerges as the master of the "Wuthering Heights", the condition of Heathcliff becomes worse. As the novel explicates the immoral actions of the Victorian aristocratic people or the conflict between moral values and vengeful action:

"Hindley becomes tyrannical ....... He drove him (Heathcliff) from their company to the servant deprived him of the instruction of the curate, and instead that he should labor out of the door..." (Emily Bronte 1999.p.52)

Again, the conflict between materialism and humanity becomes transparent when Catherine wants to marry Edgar Linton leaving Heathcliff even if she loves him. As she narrates her materialistic thought regarding marriage:

“.........It would degrade me to marry Heathcliff ...... (Linton) will be rich and I shall like to be the greatest woman of the neighborhood and I shall be proud of having such a husband."

So this kind of materialistic attitude dampens the love affair between Heathcliff and Catherine.

In a like manner when Heathcliff becomes wealthy, Victorian people acknowledge him as a gentleman though he loses his moral values. In the truest sense of the term, Victorian mate- realistic social norms metamorphose him from a man of good heart to a revengeful and immoral man. When Heathcliff becomes the owner of the Heights, he gets vengeful on the members of the Earnshaws family who degraded him. Even Edgar Linton's son Hareton is compelled to live "in his own house as a servant, deprived of the advantage of wages" (Emily Bronte,1999 line: 182) as punishment though he is innocent. So, Heathcliff, at least, appears as vengeful and immoral because of having no morality. 


\section{CONFLICT BETWEEN FREEDOM AND RESTRICTION}

In Victorian novels and poetry, the conflict between social or religious freedom and restriction appears to be prevalent if it is discussed with the light of sex. More clearly, in the Victorian era, the question of enjoying the freedom and being restricted with religious and social norms depended on sex. Victorian women's freedom was, in fact, sometimes limited to religious prohibitions and sometimes to social norms. They had to live with the restriction on work, movement, education, freedom of speech and even taking the decision in their weddings. Truly, Victorian women had no freedom to take the education that will enable them to be free in thoughts and actions. As the patriarchal Victorian society is oblivious to proper female education, the female part failed to add them to the main stream of societal development. It doesn't mean that they were deprived of education completely. They are technically compelled to receive a new form of education so as to they can play a role like "Angel in the house". ${ }^{2}$ These discriminative attitudes or restrictions for women have been portrayed in the Victorian poem "Angel in the House" written by Coventry Kersey Dighton Patmore (1823-1896). As the poem states:

\section{"Man must be pleased; but him to please \\ Is woman's pleasure; down the gulf \\ Of his condoled necessities}

She casts her best, she flings herself.How often flings for naught, and yokes

Her heart to an icicle or whim,

Whose each impatient word provokes

Another, not from her, but him;

While she, too gentle even to force

His penitence by kind replies,

Waits by, expecting his remorse,

With pardon in her pitying eyes;

And if he once, by shame oppress'd,

A comfortable word confers,

She leans and weeps against his breast,

And seems to think the sin was hers;

(Coventry Patmore, 1905)

In truth, this queer myth snatched women's freedom and they are captivated by the restrictions imposed by the society and it was prevalent in Victorian poetry and novels. For example, Laura Fairlie in the novel "The Women in White" (1860), Lady Isabel Carlyle in East Lynne (1861), Tess in the "Tess of the d'Urbervilles" (1891) by Willkie Collins, Ellen Wood, and Thomas Hardy respectively are like the angels in the house. Again, Victorian women had to learn how to be the attraction of their husband through their physical beauty and of course domestic abilities. A Victorian egoistic character Caroline Bingley in the novel "Pride \& Prejudice" (1813) makes a list of skills of a girl for which she will be acknowledged in the Victorian society as the perfect wife. Says she:

"A woman must have a thorough knowledge of music, singing, drawing, dancing, and the modern languages....; and besides all this, she must possess a certain something in her air and manner of walking, the tone of her voice, her address and expressions"...(Chapter. 08)

So it's an admitted fact that typical Bingley wants that women must act as to what their husbands like. They should not enjoy the freedom of receiving education in the fields they want. Because, this sort of educational system or knowledge, according to many Victorian people, downgrades a lady's dignity of becoming an "angel in the house." Moreover, "Some doctors reported that too much study actually had a damaging effect on the ovaries, turning attractive young women into dried-up prunes. Later in the century, when Oxford and Cambridge 
opened their doors to women, many families refused to let their clever daughters attend for fear that they would make themselves unmarriageable"(Gender Roles in 19 Century/ https://www.bl.uk).

Likewise, Victorian women were considered to be somewhat unfit to the public spheres included business, politics, law etc. Women's "proper sphere" is, in fact, the domestic life that includes some works- religious education, rearing children, housekeeping, cleaning, and what not- they have to do (Ashlyn Kuersten, 2003). This becomes the queer myth or an ideology "Separate Spheres."4 Which is why this strong myth existed in the Victorian era becomes a villain in the way of enjoying women's freedom and it also captivates Victorian women with the thread of different sorts of restrictions. Almost all Victorian novelists place men and women characters in different social spaces while domestic spaces are for the heroines always with few exceptions. Even though in the Victorian novel 'Great Expectations' Estella and Mrs. Joe are exceptions in this term, Miss Havisham and Pip's mother Georgiana are captivated. Being defrauded by Compeyson, Miss Havisham captivates herself in the Satis House for the whole of her life wearing wedding dresses and adopting Estella as the tool of taking revenge. In the truest sense of the term, if Miss Havisham got the freedom of filing a case against the fraud Compeyson and was able to punish him an exemplary punishment, she would not captivate herself in the house and determine to take revenge against a deceptive man. So it's avowed that the patriarchal Victorian society captivates women with its culture of impunity.

In a like manner, Pip's mother Georgiana suffers from lack of freedom. She has been treated as a slave by her husband. As Pip narrates her miserable condition:

"I see so much in my poor mother, of a woman drudging and slaving and breaking her honest heart and never getting any peace in her mortal days, that I'm dead afeerd of going wrong in the way of not doing what's right by a woman,". (Chapter- 7 P.06)

In respect of having sex or sexuality, Victorian women were different from their husbands even though they lived under the same roof. It is an acknowledged fact that men could maintain lengthy affairs with other women but the wife has to be with her husband only because she had no freedom to decide divorce as an option(Forman, 2000). Angel Clare in the Victorian Thomas Hardy's novel "Tess of the d'Urbervilles" had had an extramarital relationship with an old woman is forgiven by Tess easily but when Tess confesses her past happenings that she was compelled to have sex with Alec d'Urbervilles and gave birth to a son named Sorrow, Angel Clare unscrupulously turns her down as his wife and leave her for Brazil on the one hand and Alec d'Urvervilles is not, at least, alleged for his outrageous deed on the other hand. In the light of above discussion, it can be said assuredly that in the conflict of freedom and restriction, the restriction triumphs over freedom in every issues in Victorian society.

\section{CONCLUSION}

After a long strenuous study, it has been found that Victorian novels and poetry are replete with different sorts of ideological conflicts existed in the mind of the Victorian people and the literary writers of course. In the truest sense of the term, the Victorian crisis of faith or Darwin's theory of evolution by natural selection or scientific advancement, the rapid growth of industrialization and discriminatory attitude towards women question the religious faith, moral values and freedom of women respectively. This is because, faith, moral values and freedom of Victorian age explode into conflicts with doubt, materialistic attitude and restriction individually. It is worth concluding that in Victorian novels and poetry, we have traced the conflict between faith and doubt with an analysis of scientific advancement and the theory of evolution, the contradiction of moral values and materialistic attitudes with the consideration of social norms and the conflict between freedom and restriction in the light of sex. 


\section{NoTES}

1. Theory of Evolution coined and developed by Charles Darwin (1809-1882) and some other naturalists, concerns that all genus of organisms builds up in the course of a lengthy and slow process of natural selection that boosts the individual's capability to struggle for continuing to exist. This theory in which human's slow process of evolution is explained states that human beings are originated from apelike family (...Darwinism/ https://en.wikipedia.org and Introduction to Human Evolution/ http://humanorigins. si.edu/education). If is it so, this theory obviously questions the importance of God in the mind of the Victorian people in respect of the issue of the creation of human beings. And therefore the ideological conflict between faith and doubt arises in the mind of the Victorian poets and novelists.

2. "Angel in the House" is a social norm existed in a patriarchal Victorian society that brings to light an image of an ideal wife who should be powerless, submissive, devoted, charming, sympathetic, self-sacrificing, well-mannered, soft and of course pure as an angel is thought to be (Angel in the House/ http://academic. brooklyn.cuny.edu).

3. Dodder is a kind of plant of "leafless twining, parasitic plants in the morning glory family" without roots (Dodder/ https://www.britannica.com).

4. "Separate Spheres" is an ideology developed in Europe and North America during the Industrial Revolution (Randi Warne) in which women are considered to be for household management- cleaning, washing, rearing children, housekeeping and what not- and men are for civic obligations. Because, according to the dichotomy, their biological or physical makeup or the will of God doesn't permit women to perform tasks out of the house. After snatching freedom women are, in this way, pushed into the world of restriction.

\section{REFERENCES}

Abrams, M.H. The Mirror and the Lamp: Romantic Theory and the Critical Tradition. New York: Oxford University Press, 1971

Wrongly, E.A. Energy and the English Industrial Revolution. New York: Cambridge University Press,1931

Dickens, Charles. Hard Times. London: Bradbury \& Evans Publishers, 1854, Chapter V.

Arnold, Matthew. Culture and Anarchy. Ed Matthew Arnold. London: Cornhill Magazine, 1867-68, Chapter V

Wohlfarth, D. The initial reception of the novel "The Picture of Dorian Gray" through the Victorian (English Faculty), Freiburg im Breisgau: 2003, GRIN Verlag Publisher, ISBN 3638194078, 9783638194075

“Charles Dickens” 10 December 2017 at https://en.wikipedia.org/wiki/Charles_Dickens

Arnold, Matthew. Study of Poetry. Gloucester: Dodo Press Publisher,2009, ISBN 1409961893, 9781409961895

Walker, Hugh. The Literature of The Victorian Era. Cambridge: Cambridge University Press,1931

Landow, George. Elegant Jeremiahs: The Sage from Carlyle to Mailer. Ithaca, New York: Cornell University Press, 1986.

"Ten of the Greatest: British Poets". Mail on Sunday. Retrieved 7 November 2017

Arnold, Matthew. The Incompatibles, Irish Essays, and Others.1882; Popular edition, Smith, Elder, co..(1891),1-58

'A True Gentleman in Great Expectations' 06 August 2017 at https://www.ukessays.com/essays/englishliterature/a-true-gentleman-in-great-expectations-english-literature-essay.php

Dickens, Charles. Great Expectations, Ware, Hertfordshire: Wordsworth Classics, ISBN 1-853226-004-5,1993

American Research Journal of English and Literature

Page 10 
Conflictual Ideologies in Victorian Novels and Poetry

Suhamy, Henry. Great Expectations, Cours d' Agregation (in French), Vanves: Centre de Tele_Enseignement, 1971 p.25

Dickens, Charles. Great Expectations. London; Chapman and Hall; 1861, Chapter: 27

Dickens, Charles. Great Expectations. London: The Penguin Group Publisher,2001

Bronte, Emily. Wuthering Heights. London: The Penguin Group,1999

'Wuthering Heights' 09 November 2017 at https.//en.wikipedia.org/wiki/Wuthering Heights_\#Characters

Patmore, Coventry. The Angel in the House together with The Victories of Love. London: G. Routledge \& Sons Limited,1905, Canto: IX, Sahara, Prelude, The Wife's Tragedy, P.82

'Gender Roles in 19 Century' 15 December at https://www.bl.uk/romantics-and-victorians/articles/genderroles-in-the-19th-century

Kuersten, Ashlyn K. (2003). "Separate Spheres Doctrine". Women and the law: leaders, cases, and documents. Santa Barbara, Calif: ABC-CLIO.PP.16-17. ISBN 978-0-87436-878-9

Forman, Lisa Cody (2000). " The Politics Illegitimacy in an Age of Reform: Women, Reproduction, and Political Economy in England's New Poor Law of 1834”. Women's History.11 (4): 131-156.

'Darwinism' 06 January at https://en.wikipedia.org/wiki/Darwinism

'Introduction to Human Evolution' 27 January 2018 at http://humanorigins.si.edu/education/ introductionhuman-evolution

'Angel in the House' 17 January 2018 at http://academic.brooklyn.cuny.edu/english/melani/ novel_19c/ thackeray/angel.html

'Dodder' 28 January 2018 at https://www.britannica.com/plant/dodder

Warne, Randi R. “Making the Gender- Critical Turn”.In Jensen, Tim; Rothstein, Mikael. Secular theories on religion: current perspectives. Copenhagen, Denmark: Museum Tusculanum press.pp. 249260. ISBN 978-87-572-7

Citation: Md. Nazmul Haque, Md. Amirul Islam, Mst. Ummay Tohfa, "Conflictual Ideologies in Victorian Novels and Poetry" American Research Journal of English and Literature, vol 4, no. 1, 2018, pp. 1-11.

Copyright (C) 2018 Md. Nazmul Haque, Md. Amirul Islam, Mst. Ummay Tohfa, This is an open access article distributed under the Creative Commons Attribution License, which permits unrestricted use, distribution, and reproduction in any medium, provided the original work is properly cited. 